Purdue University

Purdue e-Pubs

$1-1-1996$

\title{
Agency Costs and the Performance Implications of International Joint Venture Internalization
}

Jeffrey J. Reuer

Purdue University

Kent D. Miller

Purdue University

Follow this and additional works at: http:// docs.lib.purdue.edu/ciberwp

Reuer, Jeffrey J. and Miller, Kent D., "Agency Costs and the Performance Implications of International Joint Venture Internalization" (1996). Purdue CIBER Working Papers. Paper 115.

http://docs.lib.purdue.edu/ciberwp/115

This document has been made available through Purdue e-Pubs, a service of the Purdue University Libraries. Please contact epubs@purdue.edu for additional information. 


\title{
Agency Costs and the Performance Implications of International Joint Venture Internalization
}

\author{
Jeffrey $\mathbf{J}$. Reuer
}

Kent D. Miller

Purdue University

\section{6-009}

Center for International Business Education and Research Purdue University

Krannert Graduate School of Management

1310 Krannert Building

West Lafayette, IN 47907-1310

Phone: (317) 494-4463

FAX: (317) 494-9658 


\title{
AGENCY COSTS AND THE PERFORMANCE IMPLICATIONS OF INTERNATIONAL JOINT VENTURE INTERNALIZATION
}

\author{
JEFFREY J. REUER
}

KENT D. MILLER

Krannert Graduate-School of Management Purdue University

1310 Krannert Building

West Lafayette, IN 47907-1310

(317) $494-4420$

Internet: reuerjx@vm.cc.purdue.edu

July 22, 1996

The authors gratefully acknowledge the helpful comments of Janet Netz and the anonymous reviewers on earlier drafts of this paper. Partial funding for this project was provided by the Purdue Research Foundation.

Forthcoming in Strategic Management Journal. 


$$
\text { sin }
$$

\section{AGENCY COSTS AND THE PERFORMANCE IMPLICATIONS OF INTERNATIONAL JOINT VENTURE INTERNALIZATION}

Recent studies have examined the determinants of international joint venture (IJV) formations and stock market reactions to such investments. Less is known, however, about the evolution of IJVs and the attendant performance implications for parent firms. This paper examines one specific type of IJV evolution, IJV internalization, whereby one firm acquires the IJV by buying out its partner(s). Standard agency theory variables are hypothesized to influence parent firm valuation effects. The results indicate that parent firm valuation effects are positively related to the parent firm equity owned by insiders and the interaction of debt financing and free cash flow. 


\section{AGENCY COSTS AND THE PERFORMANCE IMPLICATIONS OF INTERNATIONAL JOINT VENTURE INTERNALIZATION}

Previous research presents seemingly contradictory evidence regarding the parent firm performance implications of joint venture (JV) investments. Event studies generally find a positive shareholder wealth effect

associated with venture formation. ${ }^{3}$ However, JVs frequently fail to meet parent firms' objectives (e.g., Beamish, 1985; see Kogut, $1988 \mathrm{~b}$ for a review), and are often unstable and short-lived. ${ }^{2}$ While scholars have typically associated JV longevity with collaborative success and JV termination with failure, ${ }^{3}$ evidence is beginning to come forward indicating that JV termination need not reflect parent firm failure. For example, sales of venture stakes may reflect changes in parent firms' corporate strategies rather than prospects for the individual JV (Bleeke \& Ernst, 1993). Moreover, JV learning can reveal favorable expansion opportunities that promote venture internalization (Inkpen, 1995; Ittner \& Kogut, 1995).

Recent event studies of JV formations suggest agency theory may be useful for isolating the sources of parent firm valuation effects from JV investments. Lee and Wyatt (1990) conjectured that agency problems may be at the root of the negative shareholder wealth effects for the international joint venture (IJV) formations they studied. Consistent with agency theory predictions, empirical research has found that parent firm inside ownership is positively related to stock price movements associated with JV formations (Cordeiro, 1993; Wild, 1994). This finding suggests that better JV investment decisions are made.when managers' and shareholders' financial interests coincide. Wild (1994) observed that IJV formations also create more wealth for parent firm shareholders when parent firms have low levels of free cash flow or have high financial leverage for a given level of free cash flow. Cordeiro (1993) reported that parent firm abnormal returns from JV formation are also more favorable in the presence of long-term performance plans and interlocking directorates.

This paper extends the agency perspective to examine the parent-firm wealth effects associated with a specific form of venture evolution--partner buyouts. In this context, agency hazards can arise at the parent firm level due to the separation of parent firm ownership and control or at the level of the venture due to coordination problems arising from shared ownership and control. This paper considers the former agency problem by emphasizing the conflicting interests of parent firm managers and shareholders regarding organizational growth via venture buyouts. Following Wild (1994), our focus is on the parent firm's ownership structure, free cash flow, 
and capital structure. Since agency problems have been implicated in diversifying acquisitions (e.g., Amihud \& Lev, 1981; Lewellen, Loderer, \& Rosenfeld, 1985; Morck \& Yeung, 1992; Shleifer \& Vishny, 1991) and recently in $\mathrm{JV}$ formations, agency hazards are also expected to influence investments of a sequential character such as JV internalizations.

The aim of this study is to join standard agency theory arguments and event study methodology to test a contingency perspective on international joint venture (IJV) buyouts. The evidence that JVs often terminate via internalization ${ }^{4}$ suggests that the aggregate shareholder wealth effects associated with MNCs' sequential investment strategies employing IJVs may be substantial. While the termination of JVs has frequently been assumed to indicate venture failure, we offer the alternative view that such strategic moves may create value for parent firms in specific contexts.

While the hypotheses tested in this study can also apply in the domestic setting, the international context for the research design is appropriate and interesting for two reasons. First, IJVs have become an increasingly important component of firms' strategies (e.g., Hergert \& Morris, 1988). Interest among practitioners and management theorists in IJV investments is therefore an important reason for our focus on IJV buyouts. Second, beginning with the pioneering work of Franko (1971), much of the theoretical and empirical work on JV ownership instability has been conducted in the international setting. Hence, focusing on IJVs facilitates comparability with previous research.

This paper begins by highlighting the most recent theoretical and empirical work in the area of JV ownership instability. Feasible evolutionary paths for JVs are identified in order to provide further motivation for focusing on partner buyouts. Hypotheses drawn from agency theory are presented in the following section. These hypotheses aid in identifying specific contexts in which IJV buyouts should be value-enhancing or valuedestroying. A subsequent section discusses the data sources and the event study methodology used to test the hypotheses. For the sample as a whole, our empirical findings do not reveal significant shareholder wealth effects from IJV buyouts. However, abnormal returns are positively related to the parent firm's inside ownership and the interaction of debt financing and free cash flow. Gains or losses from IJV termination are thus context-dependent. Following the presentation of empirical findings, the paper concludes by discussing results, limitations of the study, and avenues for future research. 


\section{JOINT VENTURE OWNERSHIP EVOLUTION}

Focusing on joint venture evolution challenges prevailing notions of what constitutes venture success. Theoretical and empirical research on JVs has often, explicitly or implicitly, characterized JV ownership structure changes as "failures" by emphasizing JV longevity or survival as indicators of success (Hamel, 1991). Such measures are appropriately applied in studies taking the JV as the unit of analysis, but have the shortcoming of not recognizing that venture evolution may produce unequal payoffs for the parent firms (Geringer \& Hebert, 1991). Focusing on the learning process in international alliances, Hamel takes issue with the use of longevity and harmony as success metrics:

Where internalization [of the partner's skills] is the goal, the longevity and 'stability' of partnerships may not be useful proxies for collaborative success... A long-lived alliance may evince the failure of one or both partners to learn... [W] [Were a failure to learn is likely to undermine the competitiveness and independence of the firm, such contentedness should not be taken as a sign of collaborative success (1991: 101).

By contrast, Parkhe offers an intermediate position in defense of longevity as a proxy for alliance success:

It must be clearly noted that longevity is an imperfect proxy for "alliance success." Longevity can be associated, for instance, with the presence of high exit barriers. And in some alliances, success can also be operationalized in terms of other measures such as profitability, market share... Yet, achievement of these latter objectives can be thwarted by premature, unintended dissolution of the [global strategic alliance]. Furthermore, objective performance measures (e.g., GSA survival and duration) are significantly and positively correlated with parent firms' reported (that is, subjective) satisfaction with GSA performance..., so that for many research purposes the use of longevity as a surrogate for a favorable GSA outcome is probably not too restrictive (1991: 582).

In a later empirical study, Parkhe (1993) found that the expected durability of an alliance is positively related to profitability, the parent's overall performance assessment of the alliance, and favorable spillover effects on the parent firm, but not the satisfaction of the parent corporation's strategic needs. Taken together these comments suggest that it is problematic to associate JV termination with failure. Where possible, parent firm performance needs to be explicitly addressed in research on JV ownership instability.

The lack of consensus in the literature regarding the relationship between JV ownership instability and performance also likely reflects empirical studies' aggregation of $\mathrm{N}$ instability types. For instance, Franko's (1971) study examined MNCs' use of IJVs as the parent firm progressed through multinational development stages. He found that IJV instability was caused by the MNC's desire to standardize global marketing policies and rationalize production to eliminate intersubsidiary competition. The study aggregated three types of IJV ownership 
instability (i.e., increasing ownership to greater than $95 \%$, increasing ownership from a minority interest to a majority interest, and divestiture or liquidation) for analyses of corporate policies, industry effects, and country effects. Consequently, one cannot infer how changing international strategies relate to partner-specific IJV ownership changes. Examples of other studies aggregating JV instability types include Beamish (1985), Killing (1983), and Park (1992).

The implicit assumption behind such pooling of ownership instability types is that the influence of ownership determinants is invariant across different paths of JV evolution. Furthermore, aggregating different kinds of JV ownership changes might also mask differences in performance effects across distinct types of JV instability. Kogut's $(1989,1991)$ research provides an example of the clarity that can be brought to earlier empirical research aggregating JV instability types. In contrast with previous research viewing JV termination as "failure," Kogut's (1991) emphasis on the option characteristics of JVs also points to the potential for capturing value by shifting ownership structures. Partner buyout, when viewed as the exercise of a call option, can enhance shareholder wealth.

Figure 1 offers a framework for categorizing alternative paths along which a JV's ownership structure may evolve. This figure can be used to classify some of the recent literature on JV instability and to illustrate why aggregation of JV ownership instability types can be problematic for theory development. Region 1 represents $\underline{\mathrm{JV}}$ ownership stability, occurring when parents' ownership shares do not change during the time horizon under consideration. From the broader perspective of venture control, however, managing the JV may be complicated by relative bargaining power shifts not reflected in ownership shares. Such bargaining power shifts may arise as competitive priorities change, environmental conditions prompting the initial JV investment cease to exist, or one partner appropriates the other's skills (Hamel, 1991). In fact, ownership stability may exacerbate conflict and control problems if parents' specialized contributions to the JV must change and rigidity in ownership stakes prevents equitable sharing of the venture's profits as it evolves. Ultimately, however, such changes in the venture may give rise to reorganization or other ownership instability types discussed below.

Insert Figure 1 About Here 
Regions 2 through 5 represent within-JV ownership instability. Within-JV ownership instability occurs when parent firms' equity stakes change but both partners remain invested in the venture. Regions 2 and 4 indicate asymmetric changes in ownership stakes. Representing symmetric changes in equity stakes, regions 3 and 5 are infeasible in two-parent JVs since changes in equity stakes are zero-sum. Simultaneous increases or decreases in ownership for two focal parents are possible in JVs with three or more parents, however. One reason JVs offer flexibility is that parent firms can readjust ownership in a JV as the relationship and partner contributions evolve (Chi, 1994). However, such negotiated changes in the JV's ownership structure can also increase ex post transaction costs. In a study of manufacturing and retailing JVs, Blodgett (1992) found that within-JV ownership instability was more likely when there had been prior ownership renegotiations, when the JV operated in foreign markets with open investment climates, and when there was an imbalance in parent firms' initial equity stakes.

Finally, regions 6 through 9 represent discrete changes in JV governance. This type of JV instability arises when the JV ceases to exist as a separate entity for the original parent firms. Representative of region 6 is the case when parent firm i converts a JV to an internal unit, solely within its hierarchy, by acquiring its partner's equity in the JV. Region 8 is the mirror image, which occurs when parent firm i sells its stake in the venture to its partner. For subsidiaries set up between 1900 and 1975, Gomes-Casseres (1987) reported that 26.9 percent of majority-owned JVs became wholly-owned subsidiaries by 1975 ; and the proportion of IJVs transitioning to wholly-owned subsidiaries increased with greater initial ownership percentages. Kogut (1988a, 1991) found that the likelihood of termination by acquisition differed by country and JV function. Japanese JVs located in the U.S. were more apt to terminate by acquisition, as were $R \& D$ ventures and JVs with marketing or distribution activities. $\mathrm{Jv}$ in concentrated industries or those experiencing unexpectedly favorable growth were also more likely to terminate by acquisition.

Region 7 is not feasible in two-parent JVs given the zero-sum nature of ownership changes. In JVs with three or more parent firms, however, two parents may jointly acquire a third parent's stake.

Region 9 occurs when the JV is divested by both parties or is liquidated. For subsidiaries established between 1900 and 1975, Gomes-Casseres (1987) noted that 11.1 percent of IJVs were sold to outsiders or local partners by 1975 , and only 1.9 percent of IJVs were liquidated by 1975 . Kogut $(1988 \mathrm{a}, 1991)$ observed that 
production-oriented JVs in unconcentrated industries are likely to terminate via dissolution rather than acquisition. Finally, hybrid cases are also possible at the boundary of region 9 (i.e., adjacent to regions 6 and 8 ) when one parent sells its stake in an ongoing IJV to an outside party.

The diversity of JV evolutionary paths illustrated in Figure 1 and the empirical findings reviewed above suggest the performance implications of JV evolution are likely to be a function of the type of ownership evolution for each partner, parent firm attributes, and other contextual factors within and outside the exchange relationship. This paper recognizes that performance implications may be quite different for alternative types of $\mathrm{JV}$ ternination (e.g., regions 6-9). Hence, this study focuses on the internalization of an IJV by one U.S. parent firm (i.e., region 6)!

\section{THEORY AND HYPOTHESES}

The notion that managers pursue growth opportunities without regard for maximizing shareholder value has existed in the literature for some time (e.g., Berle \& Means, 1932). Agency theory posits that the separation of firm ownership and control can result in suboptimal management decisions from the vantage point of shareholders. For instance, agency theory has attributed poor acquisitions to managers' and shareholders' disparate objectives and risk preferences and shareholders' imperfect monitoring of managers (e.g., Amihud \& Lev, 1981; Lewellen, Loderer, \& Rosenfeld, 1985; Morck \& Yeung, 1992; Shleifer \& Vishny, 1991). From a normative standpoint, the theory suggests that such divergent interests can be brought into better alignment through various governance mechanisms improving agent monitoring and incentives. 5 Factors generally considered influential in serving shareholder interests include outcome-based controls, the disciplinary roles of the market for corporate control and the managerial labor market, and the monitoring function served by the board of directors.

While these factors may improve the alignment between managers' and shareholders' interests, none of them works perfectly or without cost. For example, if the managerial labor market perfectly used past performance information in revising managers' salaries, managers' objectives would parallel those of shareholders, even in corporations with diffuse ownership (Fama, 1980). Given imperfections in the monitoring and rewarding of managers, however, a moral hazard problem arises because managers do not personally reap the full benefits nor 
bear the full costs of their decisions. Hence, Jensen and Meckling suggest that decreases in managerial ownership can have adverse consequences for the firm's information gathering and investment decisions:

[I]t is likely that the most important conflict arises from the fact that as the manager's ownership claim falls, his incentive to devote significant effort to creative activities such as searching out new profitable ventures falls. He may in fact avoid such ventures simply because it requires too much trouble or effort on his part to manage or learn about new technologies. Avoidance of the personal costs and the anxieties that go with them also represent a source of on the job utility to him and it can result in the value of the firm being substantially lower than it otherwise would be (1976: 313).

It follows from agency theory that the performance implications of JV internalization decisions are contingent on the acquiring firm's management incentives. The more the interests of managers converge with those of shareholders, the lower the agency costs associated with self-serving behavior and agent monitoring. If managers' compensation is inadequately tied to corporate performance, however, managerial motivations for internalizing a JV may be at odds with those of shareholders. For example, managers might be less inclined to take advantage of the coordination benefits that $\mathrm{JV}$ internalizations make possible. Managers may fail to transfer technologies and capabilities from the internalized venture to other business units, or they might not fully integrate the newly-acquired JV into the parent firm's structure and systems. When management incentives are misaligned with shareholders' interests, managers may also neglect to acquire the most attractive JVs in the most timely manner.

When management incentives are inadequate, managers may also be apt to internalize JVs that result in wealth transfers from shareholders to managers. For example, inappropriate expansion and diversification through JV internalization can arise from the divergent risk preferences of managers and shareholders (e.g., Amihud \& Lev, 1981). In contrast to shareholders who can diversify investment risks at low transaction costs through portfolio investments, managers have great difficulty hedging the risks of central concern to them--compensation and employment risks. This divergence of risk preferences takes on growing significance as managerial incentives weaken when the parent firm's ownership becomes more diffuse. Under such circumstances, JV internalization might be undertaken in part to reduce managers' compensation or employment risks. From the shareholders' perspective, however, the purchase price of the JV will be too large, possibly resulting in a negative-NPV investment. Agency theory suggests that diversifying JV formations and internalizations in high growth markets 
may partially reflect management's attempts to assure parent firm survival and provide attractive opportunities for insiders rather than maximizing the value of the parent firm.

Agency theory therefore predicts that JV internalizations will more likely be value-enhancing investments when the interests of managers and shareholders are congruent. Firms with higher inside ownership are more apt to engage in value-creating acquisitions (Lewellen, Loderer, \& Rosenfeld, 1985) and participate in less conglomerate merger activity (Amihud \& Lev, 1981). Morck and Yeung (1992) found that firms' abnormal returns from international acquisitions were positively related to inside ownership. More generally, firms with higher inside ownership are likely to earn higher profits in high growth industries (Kesner, 1987) and earn higher risk-adjusted returns (Oswald \& Jahera, 1991) than firms with lower inside ownership. We therefore expect the parent firm performance effects of IJV internalization to be influenced by the parent firm's ownership structure.

\section{H1: Abnormal returns for the U.S. parent internalizing an IJV will be positively related to the U.S. parent's inside ownership percentage.}

Agency theory argues that an appropriate ownership structure is a key factor in motivating JV investments consistent with shareholder objectives. While hypothesis one speaks to the role played by the firm's ownership structure in aligning the incentives of managers and shareholders, it does not consider the role of management's discretion in investment decisions. Agency theory contends that firms' investment decisions are also influenced by the size of the pool of internally available funds (i.e., slack resources).

Given abundant resources for investment activity, managers are apt to grow the firm beyond its optimal size (Jensen, 1986). Ventures earning less than the firm's cost of capital may be initiated to increase the size of the firm, particularly when rewards are given through promotions rather than bonuses, or when managers' power rises significantly with increases in the resources under their control. Although external financial markets provide some degree of monitoring of investments for the sake of growth, managers can avoid such scrutiny if adequate resources exist within the firm. Jensen (1986) contends that the oil industry of the 1970s provides a case in point. Given increases in oil prices and slow industry growth, managers used internal funds to diversify outside of the industry in some of the worst performing acquisitions of the 1970s. Takeovers and threats of takeover ultimately reduced excess spending on exploration and development and led firms to pass on cash flows to shareholders. 
By contrast, firms with smaller available cash flows are less likely to engage in value-destroying venture activity due to the scrutiny of external financial markets. Such firms turn to outside investors sooner or more frequently in acquiring capital than firms with larger pools of internal funds. Instead of using cash flows on negative net present value ventures, cash flows are provided to shareholders with superior investment opportunities.

Similar to acquisitions and initial IJV investments, IJV buyouts may be influenced by the scarcity or abundance of free cash flows. When internal funds are readily available, IJV internalizations may be undertaken to increase managers' personal control over activities in a foreign country or to rationalize the previous commitment of funds to a particular market. Further, the acquisition of the partner's stake may result in improved career opportunities and status for acquiring firm managers to the possible detriment of shareholders. Expanded foreign direct investment may also diversify the firm's income stream, thereby reducing managers' compensation risk. However, international diversification may not be value-enhancing from shareholders' perspective if the international expansion does not leverage proprietary resources across markets (Morck \& Yeung, 1992).

\section{H2: Abnormal returns for the U.S. parent internalizing an IJV will be negatively related to the U.S. parent firm's free cash flow.}

Jensen's (1986) "control hypothesis" argues that the use of debt financing enables managers to promise that future cash flows will be paid out rather than invested in wealth-destroying ventures. Bondholders provide a disciplinary force because they have the legal right to take the firm into bankruptcy if this obligation is not fulfilled. The possibility of a firm failing to meet payments on its debt discourages managers from undertaking investments that might adversely impact efficiency. It follows from Jensen's (1986) reasoning that increasing the firm's leverage attenuates the negative effect of free cash flow on abnormal returns (H2). The firm with a high level of debt utilization for a given level of free cash flow will be more apt to engage in value-creating JV investment decisions.

H3: Abnormal returns for the U.S. parent internalizing an IJV will be positively related to the interaction of the U.S. parent firm's leverage and free cash flow. 


\section{METHODOLOGY}

A sample of $\mathrm{IV}$ internalization announcements was constructed using the section on U.S. investment abroad contained in Mergers \& Acquisitions for the seven-year period extending from the first quarter of 1988 through the fourth quarter of 1994. The M\&A periodical provided information on the completion date, partner names, the name of the IJV, and the location of the IJV. In order to appear in the dataset, a publicly-traded U.S. parent firm must have acquired the remaining equity stake in a non-U.S. venture. Predicast's Funk \& Scott Index and the Wall Street Journal Index were used to augment the database and to obtain announcement dates for the IJV internalizations listed in M\&A. When multiple announcements appeared for a particular IJV internalization, the earliest available date was used, and confounded announcements were not included in the analysis. When an announcement date was not available from the F\&S Index or the Wall Street Journal Index, the M\&A completion date was used as a surrogate since this date was generally on, or one day prior to, the announcement date.

The following market model was used to obtain expected returns for each U.S. parent firm:

$$
R_{i t}=\alpha_{i}+\beta_{i} R_{m t}+\varepsilon_{i t}
$$

where $R_{i t}$ is the return on security $i$ for day $t, R_{m t}$ is the return of the value-weighted market portfolio (including all distributions and excluding ADRs), and $\varepsilon_{\mathrm{it}}$ is the error term assumed to be independent across firms and time, and normally distributed with mean zero and constant variance. Daily returns for each U.S. parent firm were obtained from the Center for Research in Security Prices (CRSP) datafiles. CRSP also provided data on the value-weighted market portfolio's returns. OLS parameter estimates were obtained by estimating equation (1) over the period $t=$ -250 to $t=-50$, where $t=0$ corresponds to the event date. The length and placement of the estimation period was chosen by considering recommendations that it be long enough for statistical accuracy and close to the event date (e.g., Strong, 1992) and precedent in the JV formation literature (e.g., Koh \& Venkatraman, 1991).

Firm i's abnormal return for a given day within the event period is the difference between the firm's actual return and the return predicted by equation (1):

$$
A R_{i t}=R_{i t}-\left(a_{i}+b_{i} R_{m}\right) \text {, }
$$

where $A R_{i t}$ is the abnormal return for firm $i$ on day $t, R_{i t}$ and $R_{m t}$ are as defined above, and $a_{i}$ and $b_{i}$ are the firm's OLS parameter estimates from equation (1). 
In order to capture shareholder wealth effects attributable to the IJV internalization, a five trading day event period was used to accumulate abnormal returns. Cumulative abnormal returns are thus calculated as follows:

$$
\text { (3) } \quad \mathrm{CAR}_{\mathrm{i}, \tau, \mathrm{K}}=\sum_{\mathrm{i}=\tau}^{\mathrm{K}} \mathrm{AR} \mathrm{R} \text {, }
$$

where $\tau$ and $\kappa$ were set at -2 and 2 , respectively.

The significance of abnormal returns during the announcement period can be assessed through standardization. ${ }^{6}$ Due to the possible influence of outlying abnormal returns, however, the nonparametric sign test (Siegel, 1956) was also used:

(4) $\quad Z_{b}=\frac{P-0.5 \mathrm{~N}}{0.5 \sqrt{\mathrm{N}}}$

The test statistic $\mathrm{Z}_{b}$ follows a standard normal approximation to the binomial distribution under the null hypothesis that IJV internalizations have no effect on abnormal returns. $P$ is the number of firms experiencing positive abnormal returns, and $\mathrm{N}$ is the sample size.

To test the three hypotheses developed in the previous section, the following cross-sectional model was estimated:

$$
\mathrm{CAR}_{\mathrm{i}, \tau, \mathrm{K}}=\beta_{0}+\beta_{1} \mathrm{OWN}_{\mathrm{i}}+\beta_{2} \mathrm{FCF}_{\mathrm{i}}+\beta_{3} \mathrm{LEV}_{\mathrm{i}}+\beta_{4} \mathrm{FCF}_{\mathrm{i}} \cdot \mathrm{LEV}_{\mathrm{i}}+\beta_{5} \mathrm{ASSETS}_{\mathrm{i}}+\varepsilon_{\mathrm{it}}
$$

where $O W N_{i}$ is the percent of stock held by U.S. parent firm i's officers and directors. Data on inside ownership were obtained from the Compact Disclosure CD-ROM package for the quarter closest to the internalization event. U.S. parent firm i's free cash flow, $\mathrm{FCF}_{\mathrm{i}}$, is estimated as income before extraordinary items plus depreciation and amortization less capital expenditures, which is then scaled by dividing by the parent firm's market value on the event date. LEV $_{i}$ is total liabilities divided by total assets for U.S. parent firm i. Finally, ASSETS is the natural logarithm of the U.S. parent firm's total assets (in millions of dollars), which is included to control for firm size. Previous research has reported inconsistent findings on the influence of firm size. While larger firms are expected to have smaller abnormal returns, provided gains from IJV formations are symmetric, this hypothesis has often been contradicted (e.g., Chen, Hu, \& Shieh, 1991; Crutchley, Guo, \& Hansen, 1991). Large size may also reflect the presence of supporting resources or scale economies. An ideal control variable would be the size of the IJV 
internalization relative to parent firm size, yet insufficient data were available on IJV internalization size. Data on free cash flow, liabilities, and assets were obtained from Compustat for the year prior to the internalization event. Market value data used to scale free cash flow were obtained from the CRSP datafiles.

Equation (5) indicates free cash flow has both a direct and a leverage-moderated effect on abnormal returns. The total effect of free cash flow on abnormal returns is given by the partial derivative of equation (5) with respect to free cash flow (i.e., $\beta_{2}+\beta_{4} L E V_{i}$ ). This expression indicates that the relation of free cash flow on abnormal returns is modeled as a linear function of leverage.

Prior empirical research has examined the possibility of a nonlinear relation between inside ownership and corporate performance. For example, Morck, Shleifer, and Vishny (1988) found a nonlinear and nonmonotonic relation between board ownership and Tobin's $Q$. Indicator variables were defined for the three categories of internal ownership, as identified by Morck, Shleifer, and Vishny (1988):

$\mathrm{D} 1=1$ if $\mathrm{OWN}_{\mathrm{i}} \leq .05$,

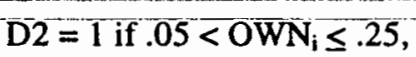

$\mathrm{D} 3=1$ if $\mathrm{OWN}_{\mathrm{i}}>.25$.

In each case, the indicator variable took on a value of 0 if the stated condition was not met. The following variant of model (5) was also estimated:

$$
\begin{aligned}
\mathrm{CAR}_{\mathrm{i}, \tau, \mathrm{K}}= & \beta_{0}+\beta_{11} \mathrm{D} 1 \bullet O W N_{i}+\beta_{12} \mathrm{D} 2 \bullet O W N_{i}+\beta_{13} \mathrm{D}_{3} \bullet O \mathrm{WN}_{\mathrm{i}}+\beta_{2} \mathrm{FCF}_{\mathrm{i}}+\beta_{3} \mathrm{LEV}_{\mathrm{i}}+\beta_{4} \mathrm{FCF}_{\mathrm{i}} \bullet \mathrm{LEV}_{\mathrm{i}}+ \\
& \beta_{5} \mathrm{ASSETS}_{\mathrm{i}}+\varepsilon_{\mathrm{i} \bullet}
\end{aligned}
$$

Apart from the interaction effects between inside ownership and inside ownership indicator variables, regressors are the same as in equation (5). This methodology avoids the biases introduced into parameter estimates using the approach taken by Morck, Shleifer, and Vishny (1988) and Wild (1994). ${ }^{7}$ A hierarchical F-test based on the overall fit of equation (5') relative to the constrained model (i.e., equation 5) provides a test for the hypothesis that the effect of inside ownership on IJV internalization valuation effects is identical across the three inside ownership categories (i.e., $\left.\beta_{11}=\beta_{12}=\beta_{13}\right)^{8}$ 


\section{RESULTS}

During the seven-year horizon considered, daily stock returns data were available for parent firms internalizing 88 IJVs. After merging firms' stock returns data and the ownership and financial information obtained from Compact Disclosure and Compustat, 75 IJV internalizations remained in the dataset: The sample contains U.S. parent firms operating in 23 different primary industries at the two-digit SIC code level. Forty percent of the parent firms operated in manufacturing industries in SIC codes 3000-3999. The IJVs internalized by U.S. parent firms were located in 23 different countries.

Table 1 provides descriptive statistics and correlations for the variables in equation (5). The average inside ownership percentage is 5.03 percent, and ranges from a low of 0.04 percent to a high of 42.0 percent. The average firm had a leverage ratio of 0.61 and free cash flow equal to 2.87 percent of market value. Table 1 indicates average total assets of $\$ 8.58$ billion. The correlation matrix reveals that more highly-leveraged firms and larger firms tend to have lower inside ownership.

Insert Table 1 About Here

Table 2 provides results on the valuation effects associated with IJV internalization. The table indicates that the average cumulative valuation effect of IJV internalization is not statistically different from zero for the five-day window. The proportion of firms experiencing positive abnormal returns on any given day ranges from 0.386 to 0.534 . While none of the mean cumulative abnormal returns are significantly different from zero, the nonparametric sign test shows that the proportion of negative returns is significantly more than 50 percent on trading days $t=1$ and $t=2(p<0.05)$. The proportion of firms obtaining a positive cumulative abnormal return over the entire announcement interval is 45.5 percent. The mean cumulative abnormal return is -0.299 percent for the five-day returns window. CARs range from a low of -9.23 percent to a high of 10.8 percent. These findings indicate no general pattern regarding the ex ante performance implications of IJV termination. Even after controlling for the mode of IJV termination, shareholder valuation effects are mixed.

Insert Table 2 About Here 
Table 3 presents the regression results for models (5) and (5'). Initial estimation of these two equations revealed multicollinearity due to the correlation between the free cash flow main effect and the interaction term. Variance inflation factors (VIFs) for these two regressors were 33.2 and 32.8 , respectively, much higher than the rule of thumb upper bound of ten (Neter, Wasserman, \& Kutner, 1990). In order to correct this problem, Cronbach's (1987) centering procedure was used whereby the means for free cash flow and leverage were subtracted from the direct effects prior to forming the multiplicative tern. VIFs for the mean-differenced free cash flow and interaction variables were 1.1 and 1.2 , respectively. Following the correction for multicollinearity, regression diagnostics obtained from estimating equations (5) and (5') also indicated outlier observations. Two oütlier öbservations with studèntized residuals exceeding 2.5 in absolute value were eliminated from the analysis.' Table 3 presents the results of the two regression models after corrections were made for multicollinearity and outlier observations. .

The regression results indicate support for the hypothesis that abnormal returns from IJV internalization are positively related to the U.S. parent firm's inside ownership percentage. The model using the inside ownership percentage variable (equation 5) demonstrated a positive relation. The regression results for equation (5') suggest that the positive relationship between inside ownership and valuation effects holds only in the $25-100$ percent range. However, the F-test comparing the full and reduced models indicates the coefficients do not differ significantly across ownership categories (i.e., $F(2,65)=0.179, p>0.10$ ). A piecewise linear regression model allowing intercept terms and ownership coefficients to differ across ownership categories produced the same insignificant result. These findings may be driven in part by the small sample sizes in the highest two ownership categories, however. Only three JVs had a U.S. parent firm with an inside ownership percentage in the 25-100 percent range. Seventeen JVs had a U.S. parent firm with an inside ownership percentage in the 5-25 percent range. The finding of a positive relationship between inside ownership and IJV internalization valuation effects parallels previous work noting the positive performance effects of inside ownership for JV formations (Cordeiro, 1993; Wild, 1994) and acquisitions (e.g., Lewellen, Loderer, \& Rosenfeld, 1985; Morck \& Yeung, 1992). 
In order to assess the influence of free cash flow on valuation effects, equations (5) and (5') were estimated by dropping the free cash flow main effect and the multiplicative term. ${ }^{10}$ In both cases the hierarchical F-value was significant at slightly more than the five percent significance level (i.e., $F(2,67)=2.80$ and $F(2,65)=$ 2.86, respectively). Examination of the relative magnitudes of the free cash flow main effect and interaction term indicates the interaction effect dominates the relation with abnormal returns. Differentiating equation (5) with respect to free cash flow and substituting the OLS parameter estimates, we find:

$$
\frac{\partial \mathrm{CARK}, \tau}{\partial \mathrm{FCF}}=0.0007+0.481 \mathrm{LEV}
$$

Recalling that LEV has been centered about its mean, it can be shown that free cash flow is negatively related to shareholder wealth effects when leverage is less than $0.610 .{ }^{11}$ Applying the same analysis to equation (5') yields an equivalent result. The median leverage ratio is 0.617 for this sample, indicating a negative relation for roughly half of the parent firms. Equivalently, the relation between free cash flow and abnormal returns is negative for firms-with debt-to-equity ratios less than 1.56

Hence, contrary to $\mathrm{H} 2$, the results suggest no general relation between free cash flow and abnormal returns from IJV buyouts. Rather, the effects of free cash flow on returns are contingent on financial leverage. Support for this contingent relation is consistent with hypothesis 3 . In both equations (5) and (5'), the positive interaction term coefficient is significantly different from zero at the five percent significance level. This interaction indicates that for a given level of free cash flow, abnormal returns rise with the parent firm's financial leverage. Jensen's (1986) "control hypothesis" appears to apply to IJV internalizations as well as initial IJV investments.

The coefficient on firm size is positive in both models, but is significant at the ten percent significance level for equation (5) only. This result contrasts previous empirical studies of JV formations (Koh \& Venkatraman, 1991; McConnell \& Nantell, 1985) finding that larger parent firms obtain smaller abnormal returns.

As a check on the robustness of the results, equations (5) and ( $\left.5^{\prime}\right)$ were also estimated using three- $(t=-1$, $0,1)$ and four-day $(t=-2,-1,0,1)$ event windows for cumulative abnormal returns. Inside ownership had a positive and significant effect $(p<.03)$ on parent firm valuation effects in the four-day model, but was not significant (at the .10 level) in the three-day model. As before, the effect of ownership was identical across ownership categories. The interaction effect of leverage and free cash flow was positive and significant in both 
models ( $p<.03$ and $p<.07$, respectively), and F-tests indicated that the total effect of free cash flow was significant in both models ( $p<.01$ and $p<.07$, respectively). Size was marginally significant $(\mathrm{p}<.10)$ and positively signed in the four-day model.

\section{DISCUSSION}

Recent empirical research by Cordeiro (1993) and Wild (1994) applied agency theory and event study methodology to isolate the sources of firm value changes resulting from JV formation. This paper examined the ownership structure, free cash flow, and control hypotheses of Jensen and Meckling (1976) and Jensen (1986) in the context of IJV internalizations. Agency theory has been found useful in explaining invesiment decision ${ }^{-}$ behavior in acquisitions and IJV formations as well as the sources of stockholder wealth effects resulting from these investments. Given that joint ventures are often stepping stones to greater market commitment through a partner's buyout of the venture, this paper has sought to determine if IJV internalization is similarly subject to

\section{agency hazards.}

This research challenges two basic assumptions in prior JV research. First, we questioned JV researchers' undifferentiated treatment of alternative JV ownership changes. Future JV research will benefit from clearly defining the scope of JV ownership changes in studies considering JV ownership evolution and parent firm performance effects. While our focus was on venture partner buyouts, Figure 1 offers a taxonomy for distinguishing possible JV ownership changes. Future research might explicitly test for differential performance effects across $\mathrm{JV}$ instability types. Future empirical work might also investigate potential asymmetries in parent firm performance effects, which were not examined here due to data limitations.

Second, this research sought to theoretically and empirically examine whether JV termination is indicative of failure. The empirical findings provide no general evidence that termination of IJVs through partner buyouts constitutes failure, at least not if failure is defined in terms of negative abnormal returns to the acquiring firm. The empirical evidence indicates no general case for wealth creation or destruction associated with venture internalization. On average, the parent firm valuation effects of IJV internalization were not significantly different from zero. The empirical evidence that the performance implications of IJV termination vary, even after controlling for the termination mode, cautions against interpreting $\mathrm{JV}$ termination as collaborative failure. 
Variables drawn from agency theory aided in determining the sources of shareholder wealth effects. Like acquisitions and JV formations, IJV internalization is subject to agency hazards. This finding held despite the many possible motivations for internalizing JVs in the international environment (e.g., differences in legal regimes, competitive environments, and cultures) which might have overwhelmed the effects postulated by agency theory.

Ownership structure, the existence of resources which may be invested in suboptimal ventures, and the monitoring role of debt all influence the valuation effects on U.S. parent firms' shareholders. Following empirical work on acquisitions and JV formations, the study found that stock market reactions to IJV internalization decisions depend on the extent to which managerial and shareholder interests are aligned. When insider's have a high stake in the U.S. parent firm or when opportunities to waste internal resources are limited (due to high financial leverage), the valuation effects associated with IJV internalization are likely to be positive.

The finding that the influence of inside ownership on parent firm valuation effects is constant across ownership categories contrasts Morck, Shleifer, and Vishny's (1988) finding that Tobin's Q is nonmonotonically related to inside ownership. This discrepancy in empirical results can be explained by the fact that our empirical analysis considers market value changes associated with a specific investment decision, IJV internalization, rather than the cumulative effect of all firm investment decisions and other factors on market valuation (i.e., Tobin's Q). However, Morck and Yeung (1992) found evidence for managerial entrenchment effects on international acquisitions. Abnormal returns were smaller when insiders owned greater than twenty percent of the acquiring firm's equity. Although care should be taken in interpreting the significance of inside ownership in our individual ownership categories, we find no evidence of entrenchment in IJV internalization decisions.

These empirical findings may also inform JV research based on option theory and other theoretical work considering the performance implications of JV investment decisions. For instance, Kogut (1991) portrayed JVs as real options to expand through the acquisition of the partner's equity in a venture. If market demand proves unfavorable, the firm is not compelled to expand. However, if demand proves unexpectedly favorable, the firm can exercise its call option by acquiring the partner's equity stake. Kogut (1991) found support for this hypothesis through an event history analysis of manufacturing JVs. The empirical evidence from the present study suggests agency theory considerations moderate the willingness of managers to engage in value-creating venture buyouts. 
The exercise of call options on JVs is most likely to be value-enhancing when management incentives are aligned with shareholder interests and financial leverage limits managers' discretionary use of free cash flows. Analysis of alternative theoretical perspectives in domestic and international settings should provide valuable extensions to this study. 


\section{ENDNOTES}

${ }^{1}$ Representative studies include Balakrishnan and Koza (1993); Chen, Hu, and Shieh (1991); Crutchley, Guo, and Hansen (1991); Koh and Venkatraman (1991); Lummer and McConnell (1990); and McConnell and Nantell (1985).

${ }^{2}$ See, for example, Blodgett (1991, 1992); Gomes-Casseres (1987); Harrigan (1985, 1986, 1988); Killing (1983); Kogut (1988a, 1989, 1991); Li (1995); Mitchell and Singh (1992); and Pennings, Barkema, and Douma (1994). ${ }^{3}$ See, for example, Anderson (1990); Brown, Rugman, and Verbeke (1989); Dymsza (1988); Parkhe (1991); Ring and Van de Ven (1994); and Teece (1992).

${ }^{4}$ See Bleeke and Ernst (1993), Gomes-Cásseres (1987), Kogut (1988a, 1988b, 1989, 1991), and Mitchell and Singh (1992).

${ }^{5}$ See Eisenhardt (1989) for a review of agency theory's prospects in the management literature.

${ }_{6}^{6}$ Standardized abnorinal returns are calculated by dividing the abnormal return for firm $i$ at time $t$ by the standard error of the forecast:

(1) $\quad \mathrm{SAR}_{\mathrm{it}}=\mathrm{AR}_{\mathrm{it}} /\left[\mathrm{s}_{\mathrm{i}}\left\{1+(1 / \mathrm{T})+\left[\left(\mathrm{R}_{\mathrm{mt}}-\mathrm{R}_{\mathrm{m}}\right)^{2} / \sum_{\mathrm{j}}^{\mathrm{T}}\left(\mathrm{R}_{\mathrm{mj}}-\mathrm{R}_{\mathrm{m}}\right)^{2}\right]\right\}^{1 / 2}\right]$, where $s_{i}$ is the estimated residual variance from the market model regression for security $i$, $T$ is the number of days in the estimation period, $R_{m t}$ is the market return for period $t$ within the event period, $R_{m}$ is the mean market return during the estimation period, and $\mathrm{R}_{\mathrm{mj}}$ is the market return for period $\mathrm{j}$ within the estimation period. Assuming the average standardized abnormal return (ASAR $)$ is asymptotically normal with variance $1 / \mathrm{N}$, where $N$ is the number of IJV internalizations, a z-test can be performed on the statistic $\sqrt{\mathrm{N}} * \mathrm{ASAR}_{\mathrm{t}}$ for long estimation periods. Accumulating standardized abnomnal returns for each firm i over $d$ (i.e., $d=\kappa-\tau+1$ ) days yields the following:

$$
\operatorname{CSAR}_{i \tau, \mathrm{K}}=(1 / \sqrt{\mathrm{d}}) \sum_{\mathrm{i}=\tau}^{\mathrm{K}} \operatorname{SAR}_{\mathrm{it}}
$$

Assuming that SARs are independent across time and securities, the mean cumulative standard abnormal return,

CASAR $_{\tau, \mathrm{K}}$, is calculated and a z-test can similarly be performed on the statistic $\sqrt{\mathrm{N}} * \mathrm{CASAR}_{\tau, \mathrm{K}}$. 
${ }^{7}$ Morck, Shleifer, and Vishny (1988) and Wild (1994) estimated corporate performance in different research contexts using the following regressors:

\begin{tabular}{|c|c|c|}
\hline OWNO_5 & $\begin{array}{l}= \\
=\end{array}$ & $\begin{array}{l}\text { inside ownership percentage }\left(O W N_{i}\right) \text { if } O W N_{i}<0.05 \text {, } \\
0.05 \text { if } O W N_{i} \geq 0.05\end{array}$ \\
\hline OWN5_25 & $=$ & 0 if $O W N_{i}<0.05$ \\
\hline & $\begin{array}{l}= \\
=\end{array}$ & $\begin{array}{l}\left(\mathrm{OWN}_{\mathrm{i}}-0.05\right) \text { if } 0.05 \leq \mathrm{OWN}_{\mathrm{i}} \leq 0.25 \\
0.20 \text { if } \mathrm{OWN}_{\mathrm{i}}>0.25\end{array}$ \\
\hline OWN25_100 & $\begin{array}{l}= \\
=\end{array}$ & $\begin{array}{l}0 \text { if } O W N_{i}<0.25 \\
\left(O W N_{i}-0.25\right) \text { if } O W N_{i} \geq 0.25\end{array}$ \\
\hline
\end{tabular}

The coding of firms in higher ownership categories as nonzero values biases the coefficient estimates for firms in the OWN0_5 and OWN5_25 categories.

${ }^{8}$ If the coefficients for inside ownership are identical across the three ownership categories, then equation ( 5 ') reduces to equation (5). The relevant test statistic, $F^{*}=\frac{\operatorname{SSE}(5)-\operatorname{SSE}\left(5^{\prime}\right)}{d f_{5}-\mathrm{df}_{5^{\prime}}}+\frac{\operatorname{SSE}\left(5^{\prime}\right)}{-\mathrm{df}_{5^{\prime}}}$ follows an F-distribution with $\mathrm{df}_{5}-\mathrm{df}_{5^{\prime}}$ and $\mathrm{df}_{5^{\prime}}$ degrees of freedom, where $\mathrm{SSE}(5)$ is the error sum of squares for equation (5), SSE( $\left.5^{\prime}\right)$ is the error sum of squares for equation $\left(5^{\prime}\right)$ and $\mathrm{df}_{5}$ and $\mathrm{df}_{5^{\prime}}$ are the respective degrees of freedom (see Neter, Wasserman, \& Kutner, 1990).

${ }^{9}$ A plot of predicted values and residuals revealed no heteroscedasticity.

${ }^{10}$ See Kmenta (1986: 508-509) for an explanation of the F-test for total effects of variables included in interaction terms.

" Setting equation (6) equal to zero and solving for $\mathrm{LEV}$, we have $\mathrm{LEV}=(-0.0007 / 0.481)+0.611=0.610$. 


\section{REFERENCES}

Amihud, Y., \& Lev, B. 1981. Risk reduction as a managerial motive for conglomerate mergers. Bell Journal of Economics, 12: 605-617.

Anderson, E. 1990. Two firms, one frontier: On assessing joint venture performance. Sloan Management Review, 31: $19-30$.

Balakrishnan, S., \& Koza, M. P. 1993. Information asymmetry, adverse selection, and joint ventures. Economic Behavior and Organization, 20: 99-117.

Beamish, P. W. 1985. The characteristics of joint ventures in developed and developing countries. Columbia Joumal of World Business, 20: 13-19.

Berle, A. A., \& Means, G. C. 1932. The modern corporation and private property. New York: Macmillan.

Bleeke, J., \& Ernst, D. 1993. "The way to win in cross-border alliances. In J. Bleeke. \& D. Ernst (Eds.), Collaborating to compete: 17-34. New York: John Wiley.

Blodgett, L. L. 1991. Partner contributions as predictors of equity share in international joint ventures. Journal of International Business Studies, 22: 63-78.

Blodgett, $\mathrm{L}:-\mathrm{E}:-1992$ - Factors in the instability of international joint ventures: An event history analysis. Strategic Management Journal, 13: 475-481.

Brown, L. T., Rugman, A. M., \& Verbeke, A. 1989. Japanese joint ventures with Western multinationals: Synthesizing the economic and cultural explanations of failure. Asia Pacific Journal of Management, 6: 225-242.

Chen, H., Hu, M. Y., \& Shieh, J. C. P. 1991. The wealth effects of international joint ventures: The case of U.S. investment in China. Financial Management, 20: 31-41.

Chi, T. 1994. Trading in strategic resources: Necessary conditions, transaction cost problems, and choice of exchange structure. Strategic Management Journal, 15: 271-290.

Cordeiro, J. J. 1993. The role of director interlocks, governance, and management incentives in explaining stockholder gains from joint ventures. Academy of Management Best Paper Proceedings, 12-16.

Cronbach, L. 1987. Statistical tests for moderator variables: Flaws in analysis recently proposed. Psychological Bulletin, 87: 51-57.

Crutchley, C. E., Guo, E., \& Hansen, R. S. 1991. Stockholder benefits from Japanese-U.S. joint ventures. Financial Management, 20: 22-30.

Dymsza, W. A. 1988. Successes and failures of joint ventures in developing countries: Lessons from experience. In Contractor, F. J., \& Lorange, P..(Eds.), Cooperative strategies in international business: 403-424. Lexington, MA: D. C. Heath.

Eisenhardt, K. 1989. Agency theory: An assessment and review. Academy of Management Journal, 14: 57-74.

Fama, E. F. 1980. Agency problems and the theory of the firm. Journal of Political Economy, 88: 288-307.

Franko, L. G. 1971. Joint venture survival in multinational corporations. New York, NY: Praeger Publishers. 
Geringer, J. M., \& Hebert, L. 1991. Measuring performance of international joint ventures. Journal of International Business Studies, 22: 249-263.

Gomes-Casseres, B. 1987. Joint venture instability: Is it a problem? Columbia Journal of World Business, 22 : 97-102.

Hamel, G. 1991. Competition for competence and inter-partner learning within international strategic alliances. Strategic Management Journal, 12: 83-103.

Harrigan, K. R. 1985. Strategies for joint ventures. Lexington, MA: Lexington Books.

Harrigan, K. R. 1986. Managing for joint venture success. Lexington, MA: Lexington Books.

Harrigan, K. R. 1988. Strategic alliances and partner asymmetries. In F. J. Contractor \& P. Lorange (Eds.), Cooperative strategies in international business: 205-226. Lexington, MA: D. C. Heath.

Hergert, M.; \& Morris, D. 1988. Trends in international collaborative agreements. In F. J. Contractor \& P. Lorange (Eds.), Cooperative strategies in international business: 99-109. Lexington, MA: D. C. Heath.

Inkpen, A. C. 1995. The management of international joint ventures: An organizational learning perspective. New York, NY: Routledge.

Ittner, C. D., \& Kogut, B. 1995. How control systems can support organizational flexibility..In Bowman, E. H., \& Kogut, B. (Eds.), Redesigning the firm: 155-182. New York, NY: Oxford University Press.

Jensen, M. C. 1986. Agency costs of free cash flow, corporate finance, and takeovers. American Economic Review, 76: 323-329.

Jensen, M. C., \& Meckling, W. H. 1976. Theory of the firm: Managerial behavior, agency costs, and ownership structure. Journal of Financial Economics, 3: 305-360.

Kesner, I. F. 1987. Directors' stock ownership and organizational performance: An investigation of Fortune 500 companies. Journal of Management, 13: 499-507.

Killing, J. 1983. Strategies for joint venture success. New York: Praeger Publishers.

Kmenta, J. 1986. Elements of econometrics (2d ed.). New York: Macmillan.

Kogut, B. 1988a. A study of the life cycle of joint ventures. In F. J. Contractor \& P. Lorange (Eds.), Cooperative strategies in international business: $169-185$. Lexington, MA: D. C. Heath.

Kogut, B. 1988b. Joint ventures: Theoretical and empirical perspectives. Strategic Management Journal, 9: 319332.

Kogut, B. 1989. The stability of joint ventures: Reciprocity and competitive rivalry. Journal of Industrial Economics, 38: 183-198.

Kogut, B. 1991. Joint ventures and the option to acquire and expand. Management Science, 37: 19-33.

Koh, J., \& Venkatraman, N. 1991. Joint venture formations and stock market reactions: An assessment of the information technology sector. Academy of Management Journal, 34: 869-892. 
Lee, I., \& Wyatt, S. B. 1990. The effects of international joint ventures on shareholder wealth. The Financial Review, 25: 641-649.

Lewellen, W. C., Loderer, C., \& Rosenfeld, A. 1985. Merger decisions and executive stock ownership in acquiring firms. Journal of Accounting and Economics, 7: 209-231.

Li, J. 1995. Foreign entry and survival: Effects of strategic choices on performance in international markets. Strategic Management Journal, 16: 333-351.

Lummer, S. L., \& McConnell, J. J. 1990. Stock valuation effects of international joint ventures. In S. G. Rhee \& R. P. Chang (Eds.), Pacific basin capital market research: 531-546. North-Holland: Elsevier Science Publishers B. V.

McConnell, J. J., \& Nantell, T. J. 1985. Corporate combinations and common stock returns: The case of joint ventures. Journal of Finance, 40: 519-536.

Mitchell, W., \& Singh, K. 1992. Incumbent's use of pre-entry alliances before expansion into new technical subfields of an industry. Journal of Economic Behavior and Organization, 18: 347-372.

Morck, R., Shleifer, A., \& Vishny, R. W. 1988. Management ownership and market valuation: An empirical analysis. Journal of Financial Economics, 19: 293-315.

Morck, R., \& Yeung, B. 1992. Internalization: An event study test. Journal of International Economics, 33: 41-56.

Neter, J., Wasserman, W., \& Kutner, M. H. 1990. Applied linear statistical models. Homewood, IL: Irwin.

Oswald, S. L., \& Jahera, J. S. 1991. The influence of ownership on performance: An empirical study. Strategic Management Journal, 12: 321-326.

Park, S. H. 1992. Failure of strategic alliances: An application of transactions cost economics perspective. Unpublished doctoral dissertation, University of Oregon, Eugene, $O R$.

Parkhe, A. 1991. Interfirm diversity, organizational learning, and longevity in strategic alliances. Journal of International Business Studies, 22: 579-601.

Parkhe, A. 1993. Strategic alliance structuring: A game theoretic and transaction cost examination of interfirm cooperation. Academy of Management Journal, 36: 794-829.

Pennings, J. M., Barkema, H., \& Douma, S. 1994. Organizational learning and diversification. Academy of Management Journal, 37: 608-640.

Ring, P. S., \& Van de Ven, A. H. 1994. Developmental processes of cooperative interorganizational relationships. Academy of Management Review, 19: 90-118.

Shleifer, A., \& Vishny, R. W. 1991. Takeovers in the '60s and '80s: Evidence and implications. Strategic Management Journal, 12: 51-59.

Siegel, S. 1956. Nonparametric statistics for the behavioral sciences. New York: McGraw-Hill.

Strong, N. 1992. Modeling abnormal returns: A review article. Journal of Business Finance and Accounting, 19: 533-553.

Teece, D. J. 1992. Competition, cooperation, and innovation: Organizational arrangements for regimes of rapid technological progress. Journal of Economic Behavior and Organization, 18: 1-25. 
Wild, K. L. 1994. Managerial incentives and the valuation of international joint venture formation. Paper presented at the annual meetings of the Academy of International Business, Boston, MA. 
TABLE 1

Means, Standard Deviations, and Correlations ${ }^{\mathrm{a}}$

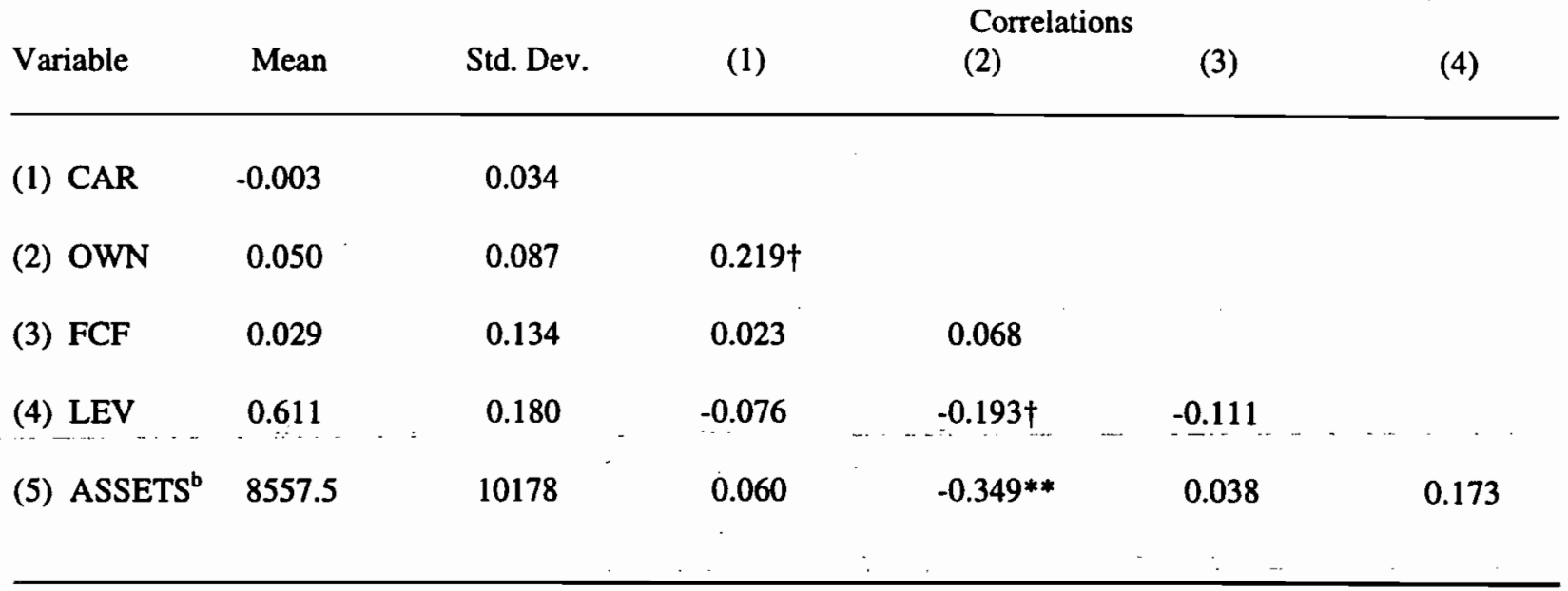

a $\mathrm{N}=75$.

b Mean, standard deviation, and correlations calculated based on actual dollar values in millions, rather than the natural $\log$ transformation as used in the regressions:

$\dagger \mathrm{p}<0.10$

$* \mathrm{p}<0.05$

** $\mathrm{p}<0.01$

$* * * \mathrm{p}<0.001$ 
TABLE 2

Acquiring Firm Valuation Effects of LJV Internalization ${ }^{c}$

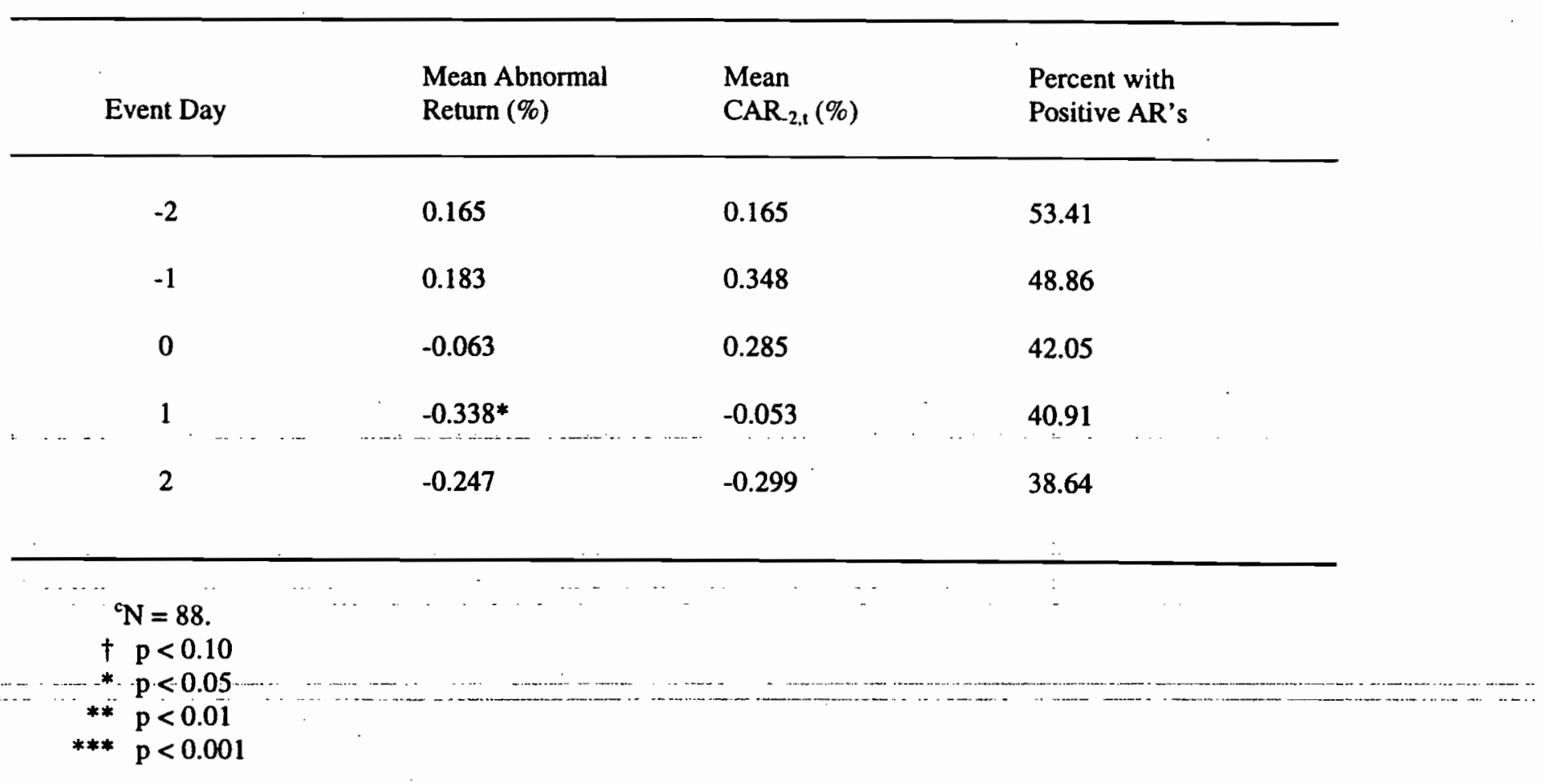


TABLE 3

Results of Multiple Regression Analyses ${ }^{d}$

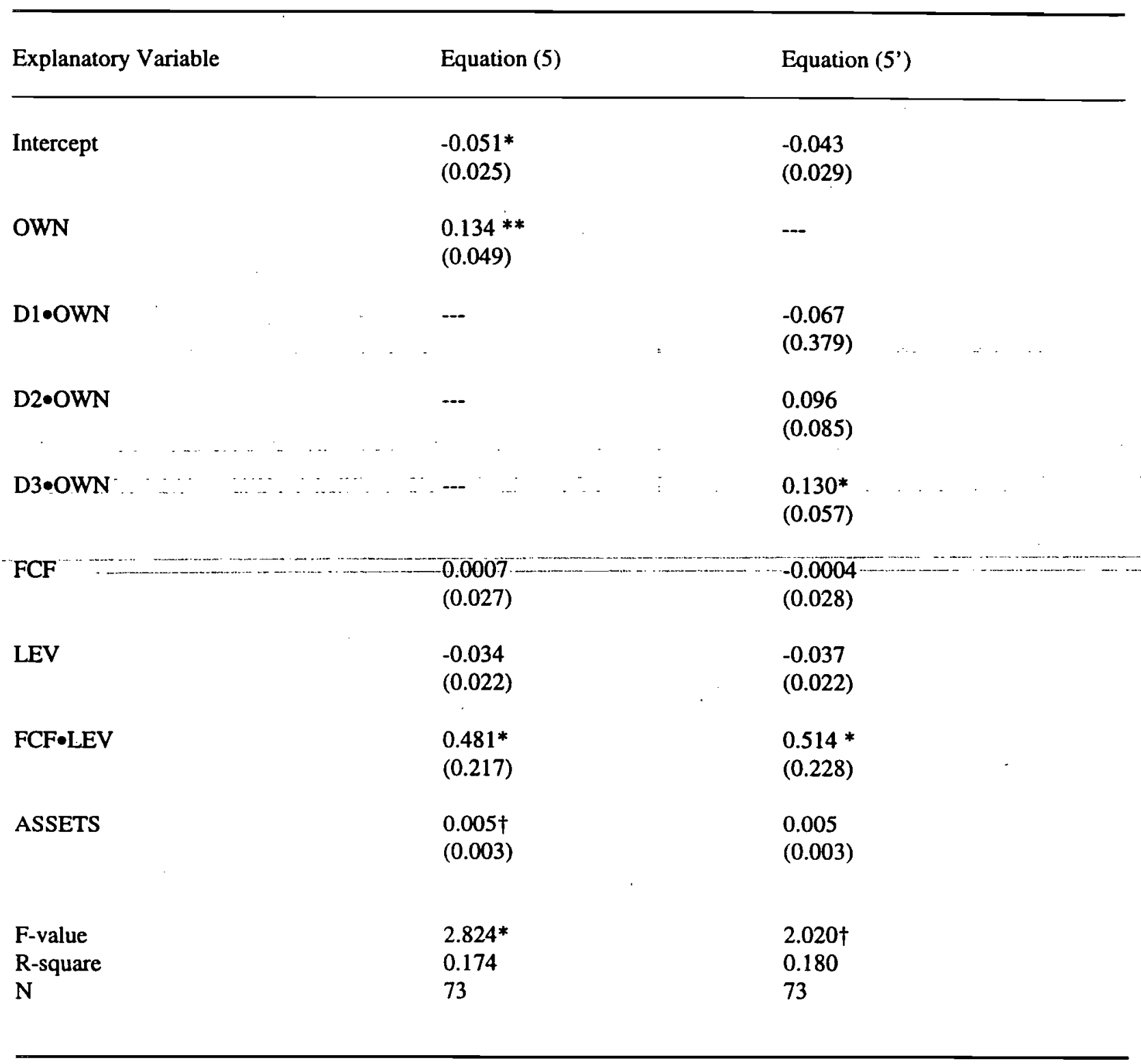

d Standard errors appear in parentheses.

$\dagger \mathrm{p}<0.10$

* $\mathrm{p}<0.05$

$* * \mathrm{p}<0.01$

$* * * \mathrm{p}<0.001$ 
FIGURE 1

Possible Types of Ownership Evolution

in Two-Parent Joint Ventures

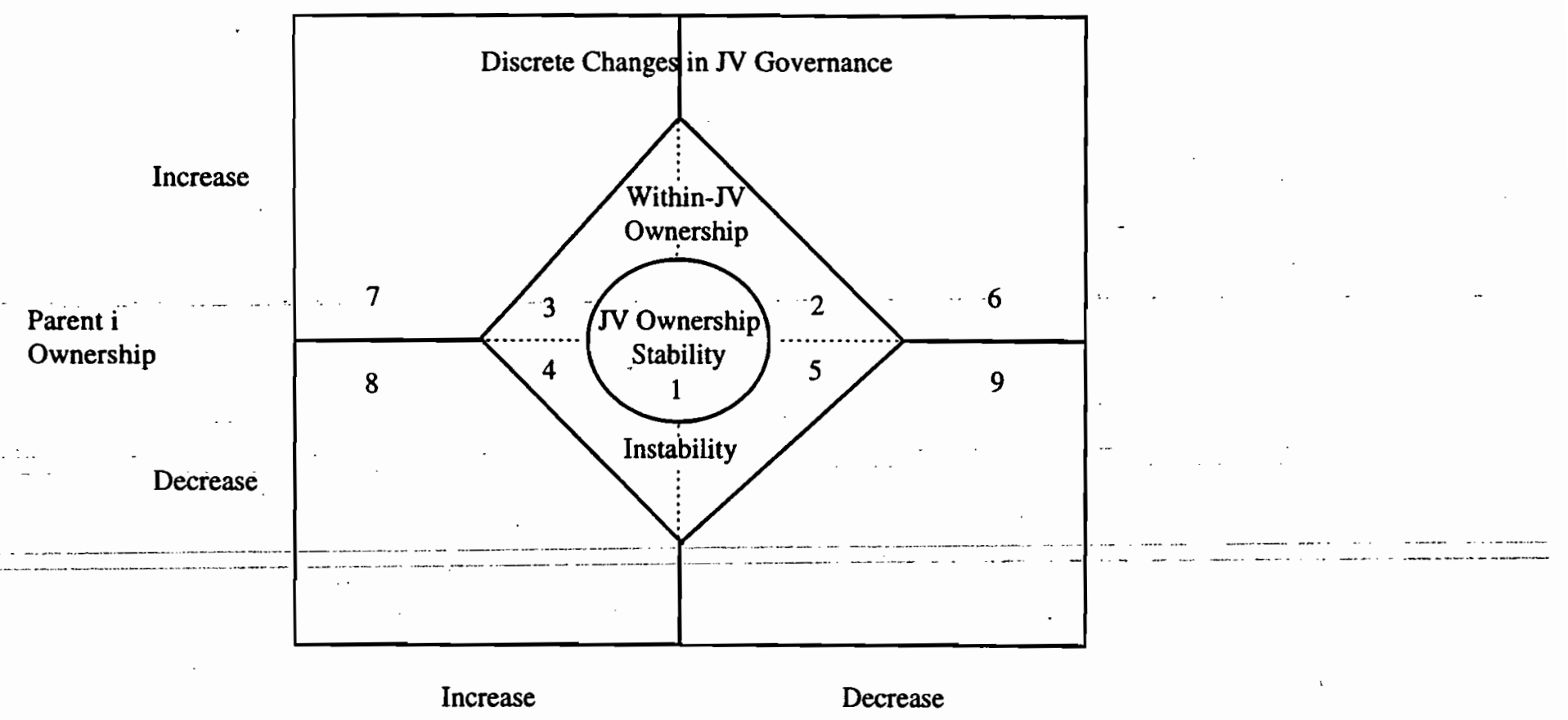

Parent j Ownership 